\title{
Pollinator enhancement in agriculture: comparing sown flower strips, hedges and sown hedge herb layers in apple orchards
}

\author{
Vivien von Königslöw ${ }^{1} \mathbb{D} \cdot$ Felix Fornoff $^{1}$ (D) Alexandra-Maria Klein ${ }^{1}$
}

Received: 18 June 2021 / Revised: 3 October 2021 / Accepted: 24 November 2021 /

Published online: 9 December 2021

(C) The Author(s) 2021

\begin{abstract}
In intensive agricultural landscapes semi-natural habitats for pollinators are often limited, although willingness to establish pollinator habitat is increasing among farmers. A common pollinator enhancement measure is to provide flower strips, but existent or improved hedgerows might be more effective. In this study, we compare the effectiveness of three pollinator enhancement measures at edges of conventional apple orchards: (i) perennial flower strips, (ii) existent hedgerows, and (iii) existent hedgerows complemented with a sown herb layer. We used orchard edges without any enhancement as control. The study took place over three consecutive years in Southern Germany. Wild bee abundance and species richness were highest in flower strips followed by improved hedges. Hoverflies were also most abundant in flower strips, but not more species rich than at control sites. Wild bee but not hoverfly community composition differed between control and enhancement sites. The overall pollinator community included only few threatened or specialized species. Flower abundance was the main driver for wild bee diversity, whereas hoverflies were largely unaffected by floral resources. Pollinator enhancement had neither an effect on the abundance or species richness within the orchards nor on apple flower visitation. Perennial flower strips seem most effective to enhance wild bees in intensive agricultural landscapes. Additionally, flower-rich hedgerows should be promoted to complement flower strips by extending the flowering period and to increase connectivity of pollinator habitat in agricultural landscapes.
\end{abstract}

Keywords Bee $\cdot$ Syrphid $\cdot$ Agro-ecology $\cdot$ Conservation $\cdot$ Integrated pest management

Communicated by Akihiro Nakamura.

Vivien von Königslöw

vivien.von.koenigsloew@nature.uni-freiburg.de

1 Nature Conservation and Landscape Ecology, University of Freiburg, Tennenbacher Straße 4, 79106 Freiburg, Germany 


\section{Introduction}

In intensively managed agricultural landscapes, semi-natural habitats are often scarce. The resulting lack of food, shelter and nesting sites is one of the main drivers of the decline in insect abundance and species richness (Dicks et al. 2021; Habel et al. 2019; Seibold et al. 2019). With increasing public awareness of the importance of insects in ecosystems, farmers increasingly apply conservation measures, especially for flagship taxa like bees. A prominent measure is to establish flower strips (Wood et al. 2017), which are shown to enhance bee diversity in different agricultural settings (Ganser et al. 2021; Haaland et al. 2011; Lowe et al. 2021), e.g., in blueberry fields (Blaauw et al. 2014), apple orchards (Campbell et al. 2017) and cereal fields (Buhk et al. 2018). Also hoverflies, another important pollinator taxa (Rader et al. 2016), benefit from flower strips (Tschumi et al. 2016). Flower strips can increase diversity of wild bees and hoverflies even in the wider landscape (Buhk et al. 2018; Jönsson et al. 2015) and thus seem to be a suitable conservation measure to enhance pollinator diversity in agricultural landscapes. However, flower strips do not cover the requirements of all potential pollinator species living in agricultural landscapes: many bees, e.g., Andrena (sand bee) species, are active before flower strips start to bloom and thus do not benefit from the additional floral resources (Campbell et al. 2017; Ouvrard et al. 2018). Furthermore, flower strips provide only limited nesting possibilities for aboveground-nesting bees, and limited larval food sources for hoverflies (Cole et al. 2020; Cope et al. 2019). Moreover, annual as well as perennial flower strips are commonly not persistent at one location, which likely limits their influence on local pollinator population growth (Pywell et al. 2011; Schmidt et al. 2020).

Hedges might be more functional to enhance pollinator diversity in agricultural landscapes (Kremen and M'Gonigle 2015; Morandin and Kremen 2013; Pfister et al. 2017; Ponisio et al. 2016). They provide habitats for many plants and animals (Dondina et al. 2016; Hinsley and Bellamy 2000; Staley et al. 2013) and are typically composed of a herb, shrub and possibly a tree layer (Maudsley 2000). The resulting plant diversity makes hedges attractive for bees and hoverflies as they find floral resources over the whole growing season with shrubs and trees blooming in spring and herbs in summer (Garratt et al. 2017; Morandin and Kremen 2013; Schirmel et al. 2018). Furthermore, hedges provide nesting sites, shelter and overwintering habitat for bumblebees, aboveground-nesting solitary bees and hoverflies (Branquart and Hemptinne 2000; Kremen and M'Gonigle 2015; Osborne et al. 2008; Rodríguez-Gasol et al. 2020, but see Lye et al. 2009).

Though of high functional importance, the herb layer of hedges is usually dominated by grasses due to eutrophication or is absent because agricultural area extends to the shrub zone (Maudsley 2000; Staley et al. 2013). A fully developed herb layer is not only itself an attractive pollinator habitat (Garratt et al. 2017; Pfiffner et al. 2018), it is also crucial for the full seasonal floral provision of hedges. We therefore assume that sowing of a flowering edge at hedges with species-poor or missing herb layer, may increase the habitat quality for pollinators.

Pollinator enhancement is of special interest in orchards as fruit production needs insect pollination for optimal yield (Garratt et al. 2014; Grab et al. 2017; Samnegård et al. 2019). Hoverflies additionally act as biological control of aphid populations, a main pest in orchards (Almohamad et al. 2009; Ramsden et al. 2017; Tschumi et al. 2016). To identify the most effective measures for enhancing the diversity of bees and hoverflies, we conducted a study in apple orchards managed according to Integrated Pest Management (IPM, Reganold et al. 2001) in Southern Germany. We investigated orchards bordered by one of 
three enhancement measures, namely flower strips, existent hedges or existent hedges complemented with a sown herb edge, in comparison to unenhanced orchards. We analyzed bee and hoverfly abundance, species richness and community composition of three consecutive years after flower strip and herb edge establishment. We tested the following hypotheses: (1a) The abundance and species richness of bees and hoverflies are higher in flower strips, unimproved hedges and improved hedges than in unenhanced orchard edges and the bee and hoverfly communities differ between the enhancement measures. (1b) The abundance of flowers drives the differences between enhancement types. (2) The abundance and species richness of bees and hoverflies is higher in the understory of orchards bordering enhancement measures compared to the understory of control sites. (3) The visitation rate of apple flowers is higher in orchards bordering enhancement measures compared to control sites.

\section{Materials and methods}

\section{Study region and orchard site selection}

The study took place at the Lake Constance region in southeast Baden-Württemberg (Germany, temperate climate) (Fig. 1; details on study sites see Annex Tab. 1), one of the largest apple-growing regions in Germany (Garming et al. 2018). We selected 18 sites located in private owned IPM-apple orchards. The sites were at least $1 \mathrm{~km}$ apart (except one case). This distance is larger than the typical foraging range of most wild bee species (Hofmann et al. 2020), exceeds the typical daily flight distance of hoverflies (Rodríguez-Gasol et al. 2020) and therefore allowed to study separate pollinator communities. Pollinators were shown to respond to the landscape context at $500 \mathrm{~m}$ radius (Kleijn and van Langevelde 2006; Meyer et al. 2009). To minimize the effect of other land-use types, all sites were

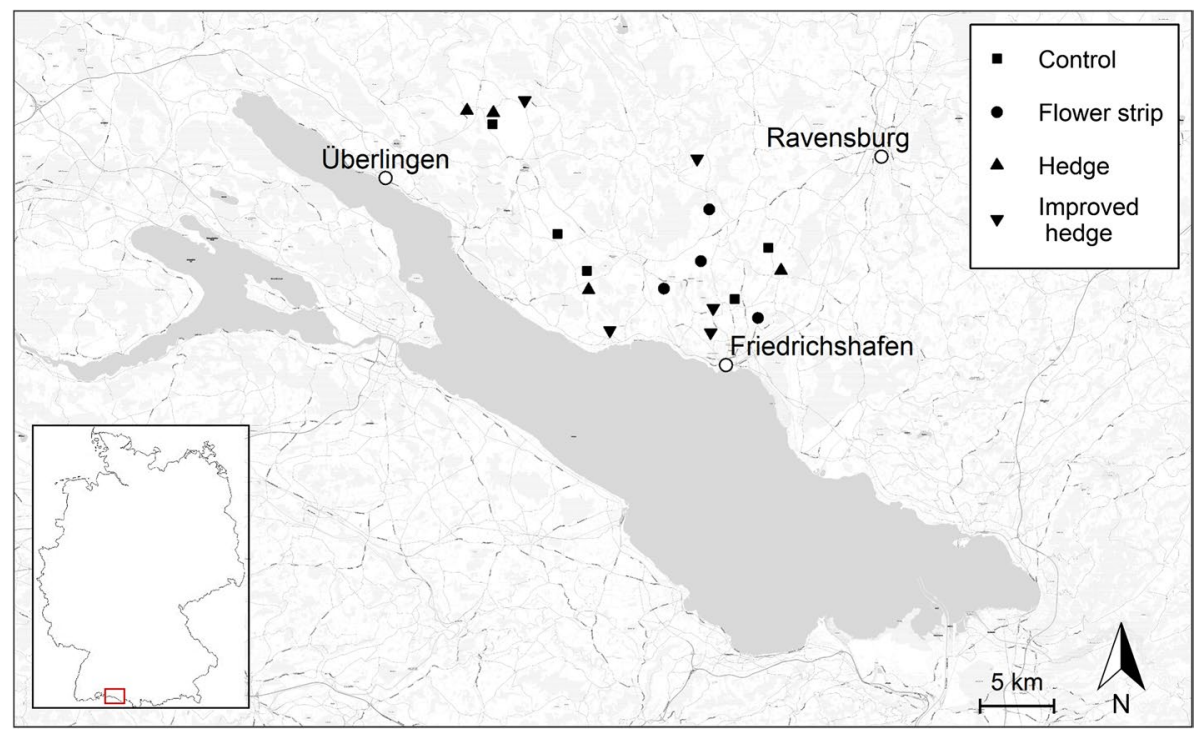

Fig. 1 Study site locations at Lake Constance 
selected to be surrounded by a large proportion of apple orchards $(53 \pm 13 \%)$ and a low amount of forest $(6 \pm 9 \%)$ in $500 \mathrm{~m}$ radius.

\section{Enhancement measures}

We selected five apple orchard sites for each of the three enhancement measures (see below) and additionally five orchards without any bordering semi-natural habitat as control sites (photos see Annex Fig. 5). One site each of the measures "flower strip" and "hedge" had to be abandoned, reducing the number of sites to 18 sites. The abandonment was caused by land owner decisions to either exit the study due to internal conflicts or to add an unintended flower strip to a hedge without prior consultation.

\section{Flower strips}

Flower strips $(n=4)$ were sown on a $25 \times 2.5 \mathrm{~m}$ area adjacent to the apple orchards at the beginning of April 2018. A perennial seed mixture containing native wild and cultivated plants of regional provenance was selected (see Annex Tabs. 2, 3).

\section{Unimproved hedges}

In this category an existent hedge $(n=4)$ bordered the orchard. The vegetation density varied from sparse to dense, and the shrub composition was variable, but all hedges, were at least 10 years old. The entire length of the hedges varied from ca. $40 \mathrm{~m}$ to $170 \mathrm{~m}$ (mean $124 \pm 49 \mathrm{~m}$ ) with none of them being connected to other habitat types. None of the hedges had a noteworthy herb layer. Where herb layers were present, these were narrow and dominated by grasses.

\section{Improved hedges}

Along five existent hedges bordering the orchards, wildflower strips were sown at an area of $0.5 \times 25 \mathrm{~m}$ in late April 2018. We selected a perennial wildflower mixture of regional provenance adapted for edges containing only native plant species (see Annex Tabs. 2, 3). In 2020, only four of the five sites could be used because at one site the orchard was turned into a field and the wildflower strip was destroyed.

\section{Sampling design}

Sampling was conducted at least once a month from late March/early April to late August/ early September in three consecutive years $(2018,2019,2020)$. During apple bloom 2018 and 2019 sampling effort was increased to allow the separate analysis of pollinators on apple flowers (three samplings during the approximately two weeks of bloom). In sum, we carried out 33-37 samplings per site. At each site and sampling day, we selected three $1 \mathrm{~m}^{3}$ plots on a predefined transect of $25 \mathrm{~m}$ length within the available enhancement measure (hedge, sown hedge herb layer, flower strip) and in the orchards (one transect at the orchard edge and one $20 \mathrm{~m}$ inside the orchards). Plots were regarded as three-dimensional to include vertical vegetation like the hedge shrubs or the apple trees (apple flowers were 
sampled as any other flowering plant). The orchard edge observation at the control sites (excluding apple flowers) was used as control in the analysis.

At each plot, we observed bees and hoverflies landing on flowers within 5 min observation time and caught them for later identification in the lab (identification literature see Annex Tab. 4). Individuals with unique characteristics were identified in the field. Bees were categorized after identification in the following subgroups following Westrich (2018): social wild (bumblebees and other social species), solitary (incl. cuckoo bees), aboveground-nesting, oligolectic (specialized at least on plant family level), threatened (at least classified as near threatened on current Red List of German bees by Westrich et al. 2012) and honeybees. Additionally, we noted for each plot at each observation day the plant species in bloom and the corresponding number of individual flowers. For plant species with tiny or composite flowers, the number of flowers was afterwards aggregated to receive floral units based on the average number of flowers per flower head (see Annex Tab. 5 for details).

Each plot was placed on areas with maximal flower cover and diversity at each sampling day individually to depict the maximum pollinator abundance, species richness and community completeness. In homogenous vegetation, this plot selection resulted in a conservative estimate, whereas in heterogeneous vegetation it resulted in an optimistic estimate. If no flowers were detectable despite intensive search, we included plots with zero plants and zero insects in the dataset. We placed the plots at sunny spots if possible. Observations took place on warm and calm days without rain $\left(25.4 \pm 4.7{ }^{\circ} \mathrm{C}\right.$, min. $13{ }^{\circ} \mathrm{C}$; wind speed $2.1 \pm 2.1 \mathrm{~m} / \mathrm{s}$, max. $11 \mathrm{~m} / \mathrm{s}$ ). We sampled each site at varying times of the day to avoid time-of-day effects. At improved hedges, we sampled three plots in the hedge and three in the sown herb layer. To receive the same number of plots at each enhancement measure in the statistical analysis for all enhancement measures, we afterwards once randomly drew three plots from the resulting six plots at improved hedges (excluding plots with zero plants and zero insects if three plots with flowers were available in order to match the selection of flower rich plots as generally conduced in all other enhancement measures).

\section{Statistical analysis}

We pooled the pollinator observations for abundance and species richness for each site and year and calculated abundance and species richness for each pollinator group. To account for the unequal numbers of samplings per year, we divided the abundance and species richness values by the number of samplings per year resulting in mean values per observation (53 replicates in total). We used Generalized Linear Models ('GLM') with a gamma distribution with log-link to test the relation of each pollinator subgroup's abundance or species richness with enhancement measure and year. As the gamma distribution does not cover zeros, we added +0.1 to all values to allow model fit. We calculated Moran's I to test for spatial autocorrelation (Dormann et al. 2007, see Annex Tab. 6) and in two cases switched from glm to glmmTMB with a structured variance-covariance matrix (exponential autocorrelation) from the R-package glmmTMB (Brooks et al. 2017) to account for spatial autocorrelation (models for abundance of all wild bees and of solitary bees). To compare the effects between enhancement measures, we calculated pairwise comparisons with the R-package lsmeans (Lenth 2016) with Bonferroni-Holm-adjustment of p-values.

To test for community differences, we used permutational multivariate analyses of variance ('adonis'; Anderson 2001) testing for enhancement measure and year using MorisitaHorn dissimilarities on $\mathrm{n}=10.000$ permutations and species' abundances per year. For 
the illustration of the species variation, we used non-metric multidimensional scaling (2-dimensional) (metaMDS) based on bray dissimilarities (Minchin 1987). For this, we combined the observations of the three years per site and omitted the site that was sampled in only two years instead of three. Species composition was tested for spatial autocorrelation using a Mantel test ('mantel'; Legendre and Legendre 2012; results see Annex Tab. 6); no autocorrelation was apparent.

To validate direct and indirect effects between predictors, we constructed structural equation models (SEM; 'psem'; Lefcheck 2016), one for each of social wild, solitary bees and hoverflies. The SEMs contained five component GLMs, each with a gamma distribution with log-link: (1) bee abundance in relation to enhancement measure, flower abundance, flower species richness and year, (2) bee species richness in relation to enhancement measure, flower abundance, flower species richness, year and bee abundance, (3) flower abundance in relation to enhancement measure and year, (4) plant species richness in relation to the enhancement measure and year and (5) a correlated error operator (\% \%) connecting plant species richness and abundance of flowers. Flower abundance (=number of floral units) was log-transformed to account for saturation effects at high flower numbers. Categorical variables (enhancement measure, year) were transformed into dummy variables.

To answer whether potential effects reached into the orchards, we applied GLMs with a gamma distribution with log-link to test the relation of pollinator abundance or species richness (social wild bees, solitary bees, hoverflies) with enhancement measure, year and location in the orchard (edge or inside) and the interaction between enhancement measure and location. For this we pooled the plots at the edge and the inside of the orchards per site and year.

To test the relation of apple flower visits with the enhancement category, we used a data subset consisting only of observations of blooming apple flowers from the plots at the edge or inside the orchards. We applied Generalized Linear Mixed-effects Models of the negative binomial family ('glmer.nb') with a control parameter (optimizer=" nlminbwrap", $\mathrm{nAGQ}=0$.) and the following predictors: enhancement category, the location in the orchard (edge or inside) plus their interaction, and the year. We applied the model on the following subgroups of pollinators: all wild bees, all bees (incl. honeybees) and all insects. The sites were included as random effect.

We conducted all analyses with R version 3.5 .3 (2019-03-11) and inspected the residual distribution of all regression models with the DHARMa R-package (Hartig 2021). The residuals conformed to the expectation in all models.

\section{Results}

Overall, we observed 4239 honeybees, 3194 wild bees from 106 species and 1425 hoverflies from 29 species (see Annex Tabs. 7, 8, 9). The abundance and species richness of both solitary and wild social bees was highest in the flower strips (Fig. 2; Annex Tab. 10). Especially social wild bee abundance and species richness was increased in flower strips (Fig. 2; Annex Tab. 11). Oligolectic bees were most abundant in improved hedges, but more species-rich in flower strips (Table 1). Red-listed bees were most abundant and species-rich in flower strips. Honeybees and aboveground-nesting bees showed no preference for one of the enhancement measures (Table 1). Hoverflies were most abundant in the flower strips, 

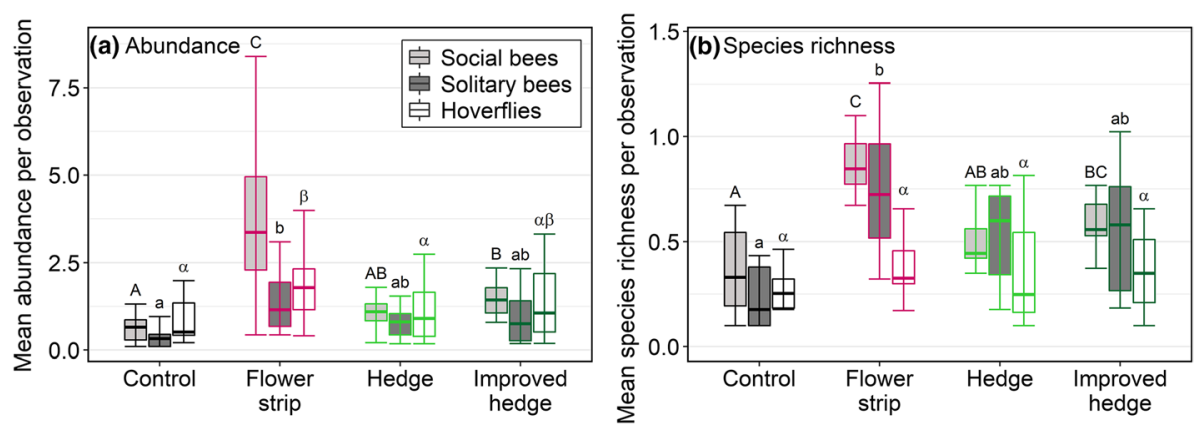

Fig. 2 Mean abundance (A) and mean species richness (B) per sampling of social wild and solitary wild bees and of hoverflies per treatment (Control, Flower strip, unimproved and improved hedge). Outliers are not shown. Letters show results of multiple comparisons of means (lsmeans); treatments with distinct letters were significantly different from each other (see also supplementary table 1). Comparisons were only tested within bee groups (social, solitary) not between bee groups. Upper case letters indicate contrasts for social wild bees, lower case letters for wild solitary bees and Greek letters for hoverflies

but species richness was not different between the enhancement measures and the control (Fig. 2; Annex Tab. 10).

Both bee and hoverfly community composition was structured by the enhancement measures (adonis: bees $\mathrm{R}^{2}=0.137, \mathrm{p}<0.001$, hoverflies $\mathrm{R}^{2}=0.147, \mathrm{p}<0.001$ ) and the year (bees $\mathrm{R}^{2}=0.031, \mathrm{p}=0.025$, hoverflies $\mathrm{R}^{2}=0.095, \mathrm{p}<0.001$ ). Wild bee but not hoverfly communities were distinct for control and enhancement measures (Fig. 3). Both bee and hoverfly communities were distinct in flower strips and hedges.

The SEM analysis revealed that all enhancement measures increased flower abundance and species richness compared to control sites (Fig. 4, Annex Tab. 11). Flower abundance was similar among the enhancement measures, whereas flower species richness was higher in flower strips and improved hedges than in hedges. Flower abundance increased both social and solitary wild bee abundance and indirectly species richness. The presence of flower strips increased social wild bee abundance directly. No direct influences of enhancement measures were identified on solitary bees. Hoverflies were not influenced by floral resources, but were driven by year-to-year variation.

Within orchards, the abundance and species richness of social and solitary bees was not influenced by the presence of any enhancement measure (Table 2). At orchard edges, solitary bee abundance and species richness was higher than inside the orchard; regardless of presence of enhancement measures. Hoverfly species richness was higher in hedges compared to flower strips and improved hedges, but not in comparison to the control (Table 2).

The number of apple flower visits by wild bees, wild bees and honeybees, or all insects was not influenced by the presence of enhancement measures (Table 3). Honeybees made up $83 \%$ of the apple flower visits, wild bees $9 \%$ and non-bees $8 \%$.

\section{Discussion}

\section{Enhancement measures}

Pollinator enhancement measures increased pollinator abundances and species richness compared to non-enhanced orchards. Among the three measures flower strips were most 
Table 1 Multiple comparisons of means for abundance and species richness of the different pollinator groups in the enhancement measures (Control, flower strip, unimproved and improved hedge) and year

\begin{tabular}{|c|c|c|c|c|c|c|}
\hline Contrast & Estimate $\pm \mathrm{SE}$ & t/z-ratio & $\mathrm{p}$-value & Estimate $\pm \mathrm{SE}$ & t/z-ratio & $\mathrm{p}$-value \\
\hline Honeybees & Abundance & & & & & \\
\hline Control - Flower strip & $-1.19 \pm 0.25$ & -4.78 & $<0.001$ & & & \\
\hline Control - Hedge & $-1.45 \pm 0.25$ & -5.79 & $<0.001$ & & & \\
\hline $\begin{array}{l}\text { Control - Improved } \\
\text { hedge }\end{array}$ & $-1.13 \pm 0.24$ & -4.72 & $<0.001$ & & & \\
\hline Flower strip - Hedge & $-0.25 \pm 0.26$ & -0.96 & 1.000 & & & \\
\hline $\begin{array}{l}\text { Flower strip - Improved } \\
\text { hedge }\end{array}$ & $0.06 \pm 0.25$ & 0.24 & 1.000 & & & \\
\hline $\begin{array}{l}\text { Hedge - Improved } \\
\text { hedge }\end{array}$ & $0.31 \pm 0.25$ & 1.23 & 1.000 & & & \\
\hline Year & & & 0.003 & & & \\
\hline All wild bees & Abundance & & & Species richness & & \\
\hline Control - Flower strip & $-1.78 \pm 0.38$ & -4.66 & $<0.001$ & $-0.99 \pm 0.19$ & -5.3 & $<0.001$ \\
\hline Control - Hedge & $-0.95 \pm 0.38$ & -2.5 & 0.096 & $-0.47 \pm 0.19$ & -2.51 & 0.072 \\
\hline $\begin{array}{l}\text { Control - Improved } \\
\text { hedge }\end{array}$ & $-1.11 \pm 0.36$ & -3.06 & 0.022 & $-0.63 \pm 0.18$ & -3.54 & 0.002 \\
\hline Flower strip - Hedge & $0.82 \pm 0.4$ & 2.05 & 0.280 & $0.52 \pm 0.2$ & 2.64 & 0.049 \\
\hline $\begin{array}{l}\text { Flower strip - Improved } \\
\text { hedge }\end{array}$ & $0.67 \pm 0.38$ & 1.75 & 0.520 & $0.35 \pm 0.19$ & 1.87 & 0.367 \\
\hline $\begin{array}{l}\text { Hedge - Improved } \\
\text { hedge }\end{array}$ & $-0.15 \pm 0.38$ & -0.4 & 1.000 & $-0.16 \pm 0.19$ & -0.87 & 1.000 \\
\hline Year & & & 0.262 & & & 0.099 \\
\hline $\begin{array}{l}\text { Aboveground- nesting } \\
\text { bees }\end{array}$ & Abundance & & & Species richness & & \\
\hline Control - Flower strip & $-1.35 \pm 0.34$ & -3.94 & $<0.001$ & $-0.96 \pm 0.19$ & -4.97 & $<0.001$ \\
\hline Control - Hedge & $-0.95 \pm 0.34$ & -2.76 & 0.035 & $-0.6 \pm 0.19$ & -3.08 & 0.012 \\
\hline $\begin{array}{l}\text { Control - Improved } \\
\text { hedge }\end{array}$ & $-1.39 \pm 0.33$ & -4.21 & $<0.001$ & $-0.73 \pm 0.19$ & -3.94 & $<0.001$ \\
\hline Flower strip - Hedge & $0.41 \pm 0.36$ & 1.12 & 1.000 & $0.37 \pm 0.2$ & 1.78 & 0.446 \\
\hline $\begin{array}{l}\text { Flower strip - Improved } \\
\text { hedge }\end{array}$ & $-0.04 \pm 0.35$ & -0.1 & 1.000 & $0.23 \pm 0.2$ & 1.17 & 1.000 \\
\hline $\begin{array}{l}\text { Hedge - Improved } \\
\text { hedge }\end{array}$ & $-0.44 \pm 0.35$ & -1.27 & 1.000 & $-0.13 \pm 0.2$ & -0.68 & 1.000 \\
\hline Year & & & 0.087 & & & 0.120 \\
\hline Oligolectic bees & Abundance & & & Species richness & & \\
\hline Control - Flower strip & $-0.93 \pm 0.4$ & -2.36 & 0.111 & $-0.67 \pm 0.15$ & -4.42 & $<0.001$ \\
\hline Control - Hedge & $-0.28 \pm 0.4$ & -0.72 & 1.000 & $-0.14 \pm 0.15$ & -0.94 & 1.000 \\
\hline $\begin{array}{l}\text { Control - Improved } \\
\text { hedge }\end{array}$ & $-1.2 \pm 0.38$ & -3.17 & 0.009 & $-0.27 \pm 0.15$ & -1.85 & 0.390 \\
\hline Flower strip - Hedge & $0.65 \pm 0.42$ & 1.55 & 0.722 & $0.53 \pm 0.16$ & 3.3 & 0.006 \\
\hline $\begin{array}{l}\text { Flower strip - Improved } \\
\text { hedge }\end{array}$ & $-0.27 \pm 0.4$ & -0.68 & 1.000 & $0.4 \pm 0.15$ & 2.6 & 0.055 \\
\hline $\begin{array}{l}\text { Hedge - Improved } \\
\text { hedge }\end{array}$ & $-0.92 \pm 0.4$ & -2.29 & 0.133 & $-0.13 \pm 0.15$ & -0.82 & 1.000 \\
\hline Year & & & 0.174 & & & 0.010 \\
\hline Red-listed bees* & Abundance & & & Species richness** & & \\
\hline
\end{tabular}


Table 1 (continued)

\begin{tabular}{|c|c|c|c|c|c|c|}
\hline Contrast & Estimate $\pm \mathrm{SE}$ & t/z-ratio & p-value & Estimate $\pm S E$ & t/z-ratio & $\mathrm{p}$-value \\
\hline Control - Flower strip & $\begin{array}{l}-0.72 \pm 0.15^{\mathrm{s}} \\
-1.39 \pm 0.22^{\mathrm{b}}\end{array}$ & $-4.83^{\mathrm{s}}$ & $\begin{array}{l}<0.001^{\mathrm{s}} \\
<0.001^{b}\end{array}$ & $-0.51 \pm 0.08$ & -6.31 & $<0.001$ \\
\hline Control - Hedge & $\begin{array}{l}-0.23 \pm 0.15^{\mathrm{s}} \\
-0.06 \pm 0.22^{\mathrm{b}}\end{array}$ & $\begin{array}{l}-6.18^{\mathrm{s}} \\
-0.28^{\mathrm{b}}\end{array}$ & $\begin{array}{l}0.686^{\mathrm{s}} \\
1.000^{\mathrm{b}}\end{array}$ & $-0.16 \pm 0.08$ & -1.92 & 0.327 \\
\hline $\begin{array}{l}\text { Control - Improved } \\
\text { hedge }\end{array}$ & $\begin{array}{l}0.00 \pm 0.14^{\mathrm{s}} \\
-0.15 \pm 0.22^{\mathrm{b}}\end{array}$ & $\begin{array}{l}0.00^{\mathrm{s}} \\
-0.67^{\mathrm{b}}\end{array}$ & $\begin{array}{l}1.000^{\mathrm{s}} \\
1.000^{\mathrm{b}}\end{array}$ & $-0.03 \pm 0.08$ & -0.38 & 1.000 \\
\hline Flower strip - Hedge & $\begin{array}{l}0.48 \pm 0.16^{\mathrm{s}} \\
1.33 \pm 0.24^{\mathrm{b}}\end{array}$ & $\begin{array}{l}3.08^{\mathrm{s}} \\
5.60^{\mathrm{b}}\end{array}$ & $\begin{array}{l}0.012^{\mathrm{s}} \\
<0.001^{\mathrm{b}}\end{array}$ & $0.35 \pm 0.09$ & 4.17 & $<0.001$ \\
\hline $\begin{array}{l}\text { Flower strip - Improved } \\
\text { hedge }\end{array}$ & $\begin{array}{l}0.72 \pm 0.15^{\mathrm{s}} \\
1.24 \pm 0.23^{\mathrm{b}}\end{array}$ & $\begin{array}{l}4.75^{\mathrm{s}} \\
5.44^{\mathrm{b}}\end{array}$ & $\begin{array}{l}<\mathbf{0 . 0 0 1}^{\mathrm{s}} \\
<\mathbf{0 . 0 0 1}^{\mathrm{b}}\end{array}$ & $0.48 \pm 0.08$ & 5.85 & $<0.001$ \\
\hline $\begin{array}{l}\text { Hedge - Improved } \\
\text { hedge }\end{array}$ & $\begin{array}{l}0.23 \pm 0.15^{\mathrm{s}} \\
-0.08 \pm 0.23^{\mathrm{b}}\end{array}$ & $\begin{array}{l}1.55^{\mathrm{s}} \\
-0.36^{\mathrm{b}}\end{array}$ & $\begin{array}{l}0.727^{\mathrm{s}} \\
1.000^{\mathrm{b}}\end{array}$ & $0.13 \pm 0.08$ & 1.53 & 0.754 \\
\hline Year & & & $\begin{array}{l}0.377^{\mathrm{s}} \\
\mathbf{0 . 0 3 2}^{\mathbf{b}}\end{array}$ & & & 0.614 \\
\hline
\end{tabular}

Negative estimates indicate lower values of first contrast elements; positive estimates indicate higher values of first elements. P-values of contrasts are Bonferroni-Holm-adjusted. For the year, Anova p-values are shown. P-values in bold are significant $(\mathrm{p}<0.05)$

*Listed at least as "Near threatened" on Red List of bees of Germany (Westrich et al. 2012)

**Red-listed solitary bees and bumblebees aggregated because of low number of red-listed bumblebee species $(\mathrm{n}=2)$

${ }^{\mathrm{s}}$ Red-listed solitary bees

${ }^{\mathrm{b}}$ Red-listed bumblebees

and hedges least attractive. Bees, especially social wild bees responded stronger than hoverflies to the enhancements. Therefore, although all enhancement measures contributed to the conservation of pollinators, flower strips seem most promising for overall wild bee conservation.

Although our number of replicates per measurement type was limited, the high number of observations per site and year is reassuring. This representativeness of our sampling was supported by the species accumulation curves, which flattened within the available number of sites and enhancement measures (see Annex Fig. 6).

\section{Bees}

Flower strips provided the most attractive floral resource for wild bees (Blaauw et al. 2014; Buhk et al. 2018; Haaland et al. 2011; Jönsson et al. 2015, but see Wood et al. 2017), especially to social wild bees. This can be explained by several factors: (1) The flowering time coincides with highest population densities of social wild bees (Westrich 2018). The flower strips bloomed from early to late summer, the months in which social wild bees are most abundant (Westrich 2018), which may also explain the occurrence of otherwise rare and threatened bumblebee species. (2) Although flower strips start flowering in late spring, 

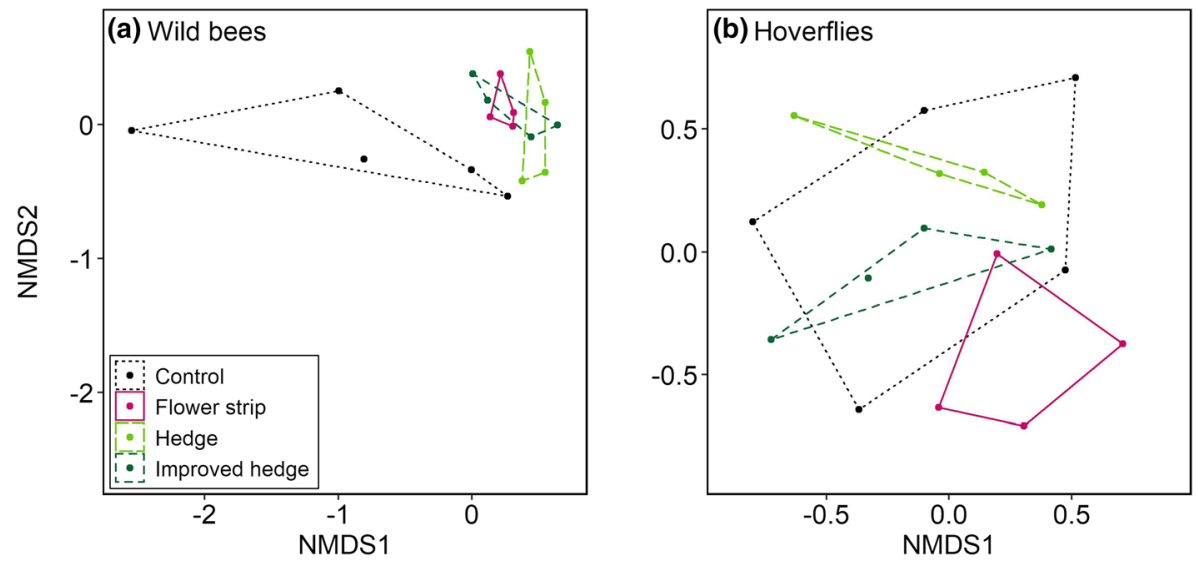

Fig. 3 NMDS ordinations using bray-curtis dissimilarity of A wild bee species composition (stress $=0.114$, adonis: $\mathrm{R}^{2}=0.137 * * *$ ) and $\mathbf{B}$ hoverfly species composition (stress $=0.193$, Adonis $\mathrm{R}^{2}=0.147 * * *$ ) per enhancement measure (Control, Flower strip, hedge, improved hedge). Dots represent experimental sites. The polygons encircle the outermost sites per treatment (function chull)

their composition allows a continuous and abundant flower cover over much of the bee foraging season. Temporally and spatially large flowering areas can be expected to increase

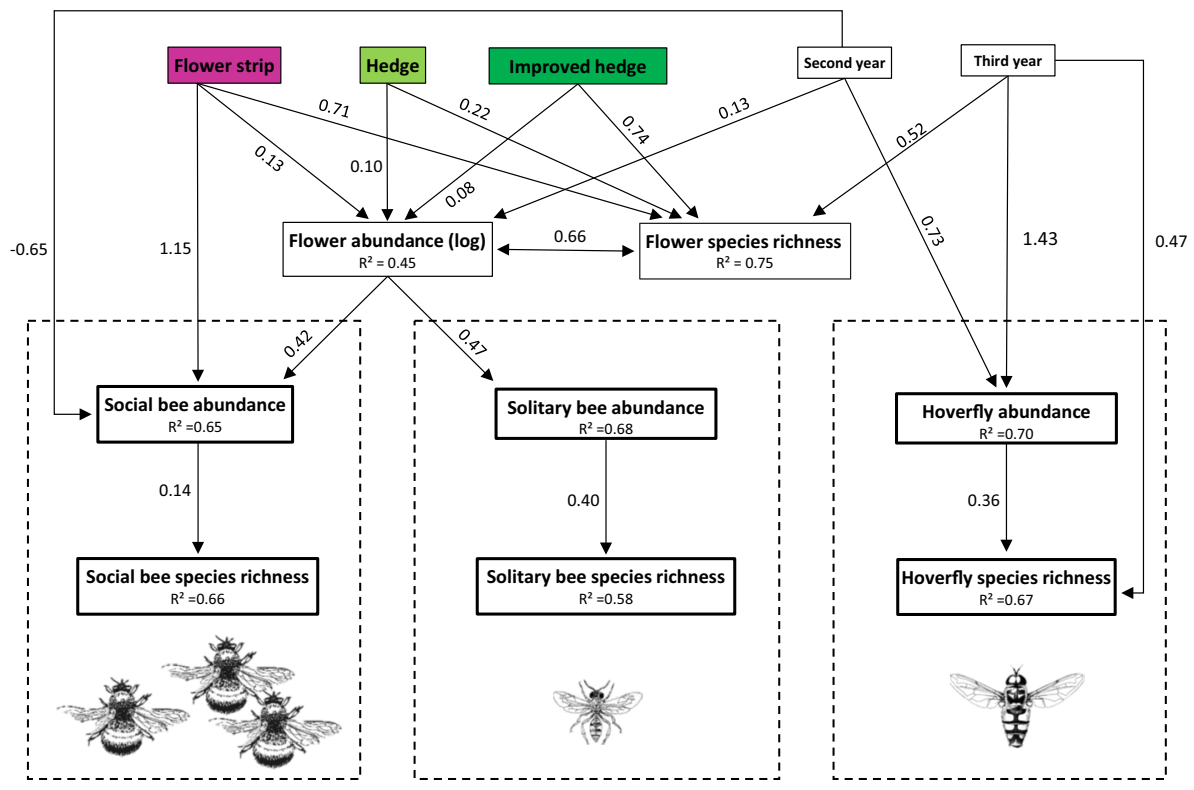

Fig. 4 Direct and indirect effects of abundance and species richness of flowering plants on social wild bees, solitary bees and hoverflies (each analyzed in separate SEMs). Only significant pathways are shown. Flower strip, hedge and improved hedge were each compared to the control. The second and third year were compared to the first year of data collection. Arrow directions show the direction of relationship and the associated numbers indicate the model estimates. $\mathrm{R}^{2}$ indicates the percent of variance in the response variable explained by the model 


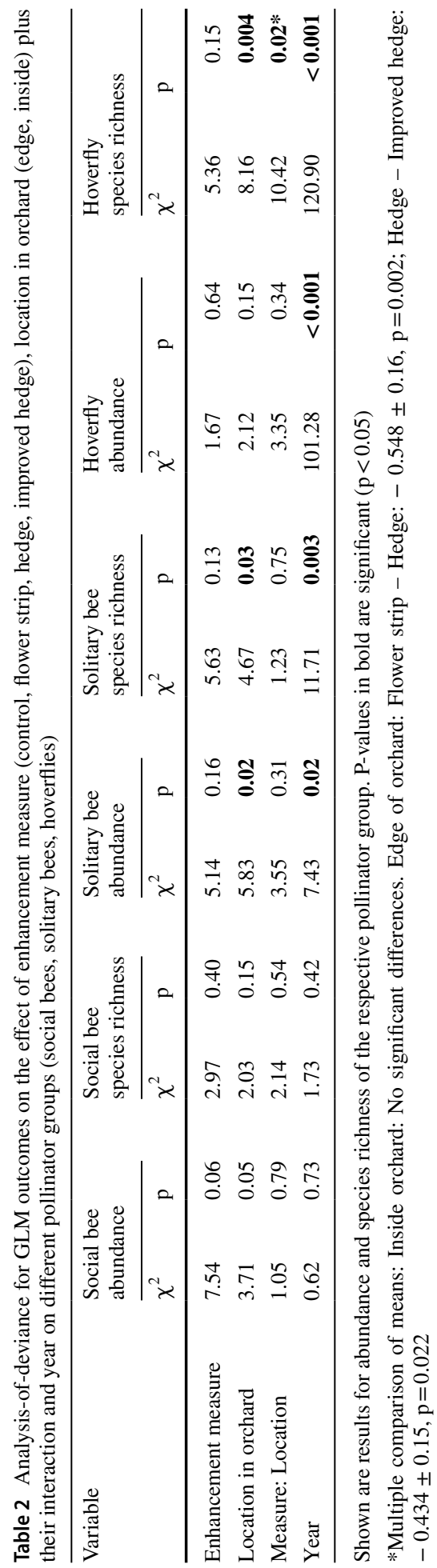


Table 3 Analysis-of-deviance for GLM outcomes on the effect of enhancement measure, location in orchard plus their interaction on different pollinator groups (all wild bees, wild bees + honeybees, all insects)

\begin{tabular}{|c|c|c|c|c|c|c|}
\hline \multirow[t]{2}{*}{ Variable } & \multicolumn{2}{|c|}{ All wild bees } & \multicolumn{2}{|c|}{ Wild bees + honeybees } & \multicolumn{2}{|c|}{ All insects } \\
\hline & $\chi^{2}$ & $\mathrm{p}$ & $\chi^{2}$ & $\mathrm{p}$ & $\chi^{2}$ & $\mathrm{p}$ \\
\hline Enhancement measure & 5.26 & 0.15 & 4.88 & 0.18 & 5.64 & 0.13 \\
\hline Location in orchard & 2.12 & 0.15 & 0.67 & 0.41 & 1.06 & 0.30 \\
\hline Enhancement measure: Location & 1.50 & 0.68 & 2.58 & 0.46 & 1.78 & 0.62 \\
\hline
\end{tabular}

Shown are results for abundance and species richness of the respective pollinator group. P-values in bold are significant $(\mathrm{p}<0.05)$

bee abundance and species richness due to the species-area relationship and the chronosequence of solitary bee species (Blaauw and Isaacs 2014). (3) The flower strips included most attractive flowering species (Rosa García and Miñarro 2014; Sutter et al. 2017). Additionally, flower strips included plant families for several oligolectic bee species e.g. Apiaceae, Asteraceae, Boraginaceae, Brassicaceae, Fabaceae and Resedaceae.

Hedges were less attractive for wild bees than flower strips. Especially social wild bees occurred in lower number and species richness. This is mostly attributable to the comparatively low flower abundance in the hedges, which mirrors the low year-round-availability and patchiness of floral resources. All hedges showed several months with low availability of floral resources, partly even in the spring months. Furthermore, some hedges were dominated by shrubs, whose flowers are relatively unattractive to wild bees, like Euonymus europaeus or Viburnum sp. (Westrich 2018, see Annex Tab. 12). Other hedges with larger amounts of e.g. Salix sp., Prunus spinosa or Rubus sp. attracted more bees, partly even oligolectic species (mostly on Salix). Though the hedges turned out less attractive as foraging habitat in our analysis, they may still play an important role for local bee populations. Social wild bees like bumblebees depend on early-flowering high-quality forage to build up their populations and hedges furthermore potentially provide nesting and hibernation possibilities (Cole et al. 2020; Hopfenmüller et al. 2014; Morandin and Kremen 2013; Scheper et al. 2015). Several oligolectic bee species depend on Willows, which often grow in hedges.

Improving hedges with a sown herb layer increased bee abundance and species richness by extending the flowering period into the summer months, but the attractiveness of improved hedges varied considerably due to differences in plant establishment success. This was partly due to the seed mixture, which lacked fast-growing annual plants, resulting in low plant cover in the first year. Furthermore, the growth conditions along the hedges were partly not adequate for the sown plant species and the narrow width of the sown herb layers facilitated growth and dominance of grasses and other unwanted plants (Graham et al. 2018). Apple trees in general reach the border of the orchard, which is where hedges typically grow, leaving only limited space for herbs. The establishment of herb layers is only promising if wide enough sunny space is available. Hedges with herb layers are thus not per se less attractive for pollinators than flower strips (Pfiffner et al. 2018), but are difficult to establish in the specific settings of intensive apple orchards.

Bee communities differed between the enhancement measures probably mostly due to differences in flowering periods. The flower strips provided most floral resources in summer, whereas peak flower in the hedges and the control orchards was in spring. Thus the flower strip community included more later-flying species, but missed out early spring 
flying species. Differences in community composition were expected from other studies, which examined pollinators in different semi-natural habitats (Pfiffner et al. 2018; Sanchez et al. 2019). Aboveground-nesting bees, which potentially rely on the reservoir of nesting sites in hedges (Morandin and Kremen 2013), were to our surprise most abundant in the flower strips (Ganser et al. 2021).

\section{Hoverflies}

Flower strips attracted the highest abundance of hoverflies (Haenke et al. 2009; Sutherland et al. 2001), followed by improved hedges, but species richness did not differ between enhancement measures and control. Adult hoverflies require nectar and pollen as food source (Almohamad et al. 2009) and diverse floral resources show positive influences on hoverfly diversity (Meyer et al. 2009; Sutherland et al. 2001). However, in our study only year, not flower abundance and species richness, explained the abundance and species richness of hoverflies. The occurrence of several easily accessible flowers from Apiaceae and Asteraceae in the flower strips and sown hedge layers, which hoverflies prefer, may play a role (Branquart and Hemptinne 2000). Yet, environmental factors like the presence of their larval food sources seem to be more important for hoverfly abundance than floral resources (Alignier et al. 2014; Schirmel et al. 2018). With more than $85 \%$ of the hoverflies in our study being aphidophagous, which is common in landscapes of high levels agricultural intensification (Inclán et al. 2016; Pfister et al. 2017), aphid population variability might be the driver of our observations. Hoverflies thus do not necessarily profit from the same measures as bees (Cole et al. 2020; Jauker et al. 2009). Several studies have shown that hedges are attractive habitat for hoverflies-even more attractive than herbaceous vegetation -, not only as foraging but also as shelter and overwintering habitat (Haenke et al. 2014; Pfister et al. 2017; Schirmel et al. 2018). It may be that our sampling method did not adequately reflect the role of hedges as shelter and overwintering habitat as hoverflies are highly mobile insects (Almohamad et al. 2009).

\section{Orchard understory flower visitation}

Within orchards the bee communities were not influenced by the enhancement measures at the orchard edges. This is not surprising because, in most cases, apart from early spring the orchards provided only scarce floral resources. Thus, bees had no reason to fly into the orchards (Olsson et al. 2015). Mowing reduces the flower abundance in orchards which may explain why the bees rarely use the orchard interiors but stay at the edges.

The hoverfly communities visiting understory flowers were also not influenced by enhancement measures. Floral resources inside the orchards are probably of little importance for hoverflies as they are no central foragers but place their eggs directly next to or in the larval food source (Almohamad et al. 2009). They can store food reserves for egg production (van Rijn et al. 2006). Thus unlike bees they do not constantly visit flowers but spend much of their time searching for oviposition sites (Rodríguez-Gasol et al. 2020). Our results suggest that flower strips and hedges are ineffective tools for increasing pest regulation by hoverflies in apple orchards, at least on the local scale. Some studies found spillover of hoverflies from semi-natural habitats to agricultural fields (Haenke et al. 2009; Sutherland et al. 2001), others not (Inclán et al. 2016; Morandin and Kremen 2013). However, 
the abundance of adult hoverflies gives only limited information on the actual level of pest regulation.

\section{Apple flower visitation}

The share of wild pollinators observed on apple flowers was low, whereas honeybees dominated the apple flower visits. Osmia bicornis was the most common apple-visiting wild bee, probably because it is managed for this purpose in the region. Other studies found much higher proportions of wild bees among apple flower visitors (Hutchinson et al. 2021). Reasons for this difference may be higher proportions of semi-natural habitat in the surrounding landscape in other studies or the intensity of honeybee-keeping in our study region (Bartholomée et al. 2020; Klein et al. 2012; Mallinger and Gratton 2015; Marini et al. 2012). Neither flower strips nor hedges increased wild pollinator visits of apple flowers. For the flower strips this is probably due to a phenological mismatch between the flight period of the main apple visiting bee species, like early-flying Andrena and Osmia, and the bloom of the flower strip (Campbell et al. 2017). Hedge shrub bloom would phenologically better fit the flight period of apple flower visiting bee species and, indeed, hedges were found to increase wild pollinator numbers e.g. in adjacent strawberry and tomato fields (Castle et al. 2019; Morandin and Kremen 2013). However, strawberries and tomatoes bloom later than apples, when e.g. social bees are naturally more abundant (Westrich 2018). In a current review, hedges were found to have no significant effect on pollination services (Albrecht et al. 2020).

\section{Conclusion}

In summary, perennial flower strips are a valuable conservation strategy to enhance bee diversity in intensive agriculture areas. Additionally, high-quality hedges should be promoted as they provide early flower resources and pollen sources for several oligolectic bee species. To increase the positive effect on specialized and threatened bee and hoverfly species and crop pollinators a long-term maintained network of flower strips complemented with other enhancement measures may be necessary (Boetzl et al. 2021; Buhk et al. 2018; Sutter et al. 2018).

Supplementary Information The online version contains supplementary material available at https://doi. org/10.1007/s10531-021-02338-w.

Acknowledgements We very much thank the orchard owners for letting us work on their properties, for inspiring discussions, and for maintaining the flower strips and flowering hedge edges with us. We especially would like to thank Christian Maus and Juliana Jaramillo for setting up the research project and continuous support. Thanks also to our scientific assistants, especially Anna-Maria Bleile, for their great support in data collection and processing. We also thank extension specialist, Katja Röser to support the study site selection and for her continuous support. Mike Herrmann and Axel Ssymank are gratefully acknowledged for identifying taxonomically ambiguous specimens.

Author contributions VvK: Conceptualization, Methodology, Formal analysis, Investigation, Data Curation, Writing - Original Draft, Visualization. FF: Formal analysis, Writing - Review and Editing. AK: Conceptualization, Methodology, Writing-Review and Editing, Funding acquisition, Supervision. 
Funding Open Access funding enabled and organized by Projekt DEAL. The research project was funded by Bayer Crop Science. Bayer Crop Science was involved in the development of the study design. Apart from that, Bayer Crop Science was not involved in the research process.

Data availability We aim to make our data and code available on an online repository in case our manuscript is accepted in Biodiversity and Conservation.

\section{Declarations}

Conflict of interest The authors have no relevant financial or non-financial interests to disclose.

Ethical approval No ethical statements are required and other approvals, i.e. the permission to catch insects for this study, were obtained from legal authorities.

Consent to participate and for publication All authors agree with the contents of the manuscript and its submission to the journal.

Open Access This article is licensed under a Creative Commons Attribution 4.0 International License, which permits use, sharing, adaptation, distribution and reproduction in any medium or format, as long as you give appropriate credit to the original author(s) and the source, provide a link to the Creative Commons licence, and indicate if changes were made. The images or other third party material in this article are included in the article's Creative Commons licence, unless indicated otherwise in a credit line to the material. If material is not included in the article's Creative Commons licence and your intended use is not permitted by statutory regulation or exceeds the permitted use, you will need to obtain permission directly from the copyright holder. To view a copy of this licence, visit http://creativecommons.org/licenses/by/4.0/.

\section{References}

Albrecht M, Kleijn D, Williams N, Tschumi M, Blaauw B, Bommarco R, Campbell A, Dainese M, Drummond F, Entling M, Ganser D, Groot A de, Goulson D, Grab H, Hamilton H, Herzog F, Isaacs R, Jacot K, Jeanneret P, Jonsson M, Knop E, Kremen C, Landis D, Loeb G, Marini L, McKerchar M, Morandin L, Pfister S, Potts S, f MR, as HS, Sciligo A, Thies C, Tscharntke T, Venturini E, Veromann E, Vollhardt I, Wäckers F, Ward K, Wilby A, Woltz M, Wratten S, Sutter L (2020) Global synthesis of the effectiveness of flower strips and hedgerows on pest control, pollination services and crop yield. Ecol Lett https://doi.org/10.22541/au.158618502.29242370

Alignier A, Raymond L, Deconchat M, Menozzi P, Monteil C, Sarthou J-P, Vialatte A, Ouin A (2014) The effect of semi-natural habitats on aphids and their natural enemies across spatial and temporal scales. Biol Control 77:76-82. https://doi.org/10.1016/j.biocontrol.2014.06.006

Almohamad R, Verheggen F, Haubruge E (2009) Searching and oviposition behavior of aphidophagous hoverflies (Diptera: Syrphidae): a review. Biotechnol Agron Soc Environ 13:467-481

Anderson MJ (2001) A new method for non-parametric multivariate analysis of variance. Austral Ecol 26:32-46. https://doi.org/10.1111/j.1442-9993.2001.01070.pp.x

Bartholomée O, Aullo A, Becquet J, Vannier C, Lavorel S (2020) Pollinator presence in orchards depends on landscape-scale habitats more than in-field flower resources. Agric Ecosyst Environ 293:106806. https://doi.org/10.1016/j.agee.2019.106806

Blaauw BR, Isaacs R (2014) Larger patches of diverse floral resources increase insect pollinator density, diversity, and their pollination of native wildflowers. Basic Appl Ecol 15:701-711. https://doi.org/10. 1016/j.baae.2014.10.001

Blaauw BR, Isaacs R, Clough Y (2014) Flower plantings increase wild bee abundance and the pollination services provided to a pollination-dependent crop. J Appl Ecol 51:890-898. https://doi.org/10.1111/ 1365-2664.12257

Boetzl FA, Krauss J, Heinze J, Hoffmann H, Juffa J, König S, Krimmer E, Prante M, Martin EA, Holzschuh A, Steffan-Dewenter I (2021) A multitaxa assessment of the effectiveness of agri-environmental schemes for biodiversity management. PNAS. https://doi.org/10.1073/pnas.2016038118

Branquart E, Hemptinne J-L (2000) Selectivity in the exploitation of floral resources by hoverflies (Diptera: Syrphinae). Ecography 23:732-742. https://doi.org/10.1111/j.1600-0587.2000.tb00316.x 
Brooks ME, Kristensen K, van Benthem KJ, Magnusson A, Berg CW, Nielsen A, Skaug HJ, Machler M, Bolker BM (2017) glmmTMB balances speed and flexibility among packages for zero-inflated generalized linear mixed modeling. R J 9:378-400. https://doi.org/10.3929/ethz-b-000240890

Buhk C, Oppermann R, Schanowski A, Bleil R, Lüdemann J, Maus C (2018) Flower strip networks offer promising long term effects on pollinator species richness in intensively cultivated agricultural areas. BMC Ecol 18:1-13. https://doi.org/10.1186/s12898-018-0210-Z

Campbell AJ, Wilby A, Sutton P, Wäckers FL (2017) Do sown flower strips boost wild pollinator abundance and pollination services in a spring-flowering crop?: a case study from UK cider apple orchards. Agric Ecosyst Environ 239:20-29. https://doi.org/10.1016/j.agee.2017.01.005

Castle D, Grass I, Westphal C (2019) Fruit quantity and quality of strawberries benefit from enhanced pollinator abundance at hedgerows in agricultural landscapes. Agric Ecosyst Environ 275:14-22. https:// doi.org/10.1016/j.agee.2019.01.003

Cole LJ, Kleijn D, Dicks LV, Stout JC, Potts SG, Albrecht M, Balzan MV, Bartomeus I, Bebeli PJ, Bevk D, Biesmeijer JC, Chlebo R, Dautartė A, Emmanouil N, Hartfield C, Holland JM, Holzschuh A, Knoben NTJ, Kovács-Hostyánszki A, Mandelik Y, Panou H, Paxton RJ, Petanidou T, Pinheiro de Carvalho MAA, Rundlöf M, Sarthou J-P, Stavrinides MC, Suso MJ, Szentgyörgyi H, Vaissière BE, Varnava A, Vilà M, Zemeckis R, Scheper J (2020) A critical analysis of the potential for EU common agricultural policy measures to support wild pollinators on farmland. J Appl Ecol 57:681-694. https://doi.org/10. 1111/1365-2664.13572

Cope GC, Campbell JW, Grodsky SM, Ellis JD (2019) Evaluation of nest-site selection of ground-nesting bees and wasps (Hymenoptera) using emergence traps. Can Entomol 151:260-271. https://doi.org/10. 4039/tce.2019.3

Dicks LV, Breeze TD, Ngo HT, Senapathi D, An J, Aizen MA, Basu P, Buchori D, Galetto L, Garibaldi LA, Gemmill-Herren B, Howlett BG, Imperatriz-Fonseca VL, Johnson SD, Kovács-Hostyánszki A, Kwon YJ, Lattorff HMG, Lungharwo T, Seymour CL, Vanbergen AJ, Potts SG (2021) A global-scale expert assessment of drivers and risks associated with pollinator decline. Nat Ecol Evol. https://doi.org/10. 1038/s41559-021-01534-9

Dondina O, Kataoka L, Orioli V, Bani L (2016) How to manage hedgerows as effective ecological corridors for mammals: A two-species approach. Agric Ecosyst Environ 231:283-290. https://doi.org/10.1016/j. agee.2016.07.005

Dormann CF, McPherson JM, Araújo MB, Bivand R, Bolliger J, Carl G, Davies RG, Hirzel A, Jetz W, Kissling DW, Kühn I, Ohlemüller R, R. Peres-Neto P, Reineking B, Schröder B, M. Schurr F, Wilson $\mathrm{R}$ (2007) Methods to account for spatial autocorrelation in the analysis of species distributional data: a review. Ecography 30:609-628https://doi.org/10.1111/j.2007.0906-7590.05171.x

Ganser D, Albrecht M, Knop E (2021) Wildflower strips enhance wild bee reproductive success. J Appl Ecol 58:486-495. https://doi.org/10.1111/1365-2664.13778

Garming H, Dirksmeyer W, Bork L (2018) Entwicklungen des Obstbaus in Deutschland von 2005 bis 2017 : Obstarten, Anbauregionen, Betriebsstrukturen und Handel. Thünen Working Paper, Braunschweig

Garratt MPD, Breeze TD, Jenner N, Polce C, Biesmeijer JC, Potts SG (2014) Avoiding a bad apple: insect pollination enhances fruit quality and economic value. Agric Ecosyst Environ 184:34-40. https://doi. org/10.1016/j.agee.2013.10.032

Garratt MPD, Senapathi D, Coston DJ, Mortimer SR, Potts SG (2017) The benefits of hedgerows for pollinators and natural enemies depends on hedge quality and landscape context. Agric Ecosyst Environ 247:363-370. https://doi.org/10.1016/j.agee.2017.06.048

Grab H, Blitzer EJ, Danforth B, Loeb G, Poveda K (2017) Temporally dependent pollinator competition and facilitation with mass flowering crops affects yield in co-blooming crops. Sci Rep 7:45296. https://doi. org/10.1038/srep45296

Graham L, Gaulton R, Gerard F, Staley JT (2018) The influence of hedgerow structural condition on wildlife habitat provision in farmed landscapes. Biol Conserv 220:122-131. https://doi.org/10.1016/j.biocon.2018.02.017

Haaland C, Naisbit RE, Bersier L-F (2011) Sown wildflower strips for insect conservation: a review. Insect Conserv Divers 4:60-80. https://doi.org/10.1111/j.1752-4598.2010.00098.x

Habel JC, Trusch R, Schmitt T, Ochse M, Ulrich W (2019) Long-term large-scale decline in relative abundances of butterfly and burnet moth species across south-western Germany. Sci Rep 9:14921. https:// doi.org/10.1038/s41598-019-51424-1

Haenke S, Scheid B, Schaefer M, Tscharntke T, Thies C (2009) Increasing syrphid fly diversity and density in sown flower strips within simple vs. complex landscapes. J Appl Ecol 46:1106-1114. https://doi. org/10.1111/j.1365-2664.2009.01685.x 
Haenke S, Kovács-Hostyánszki A, Fründ J, Batáry P, Jauker B, Tscharntke T, Holzschuh A (2014) Landscape configuration of crops and hedgerows drives local syrphid fly abundance. J Appl Ecol 51:505513. https://doi.org/10.1111/1365-2664.12221

Hartig F (2021) DHARMa: residual diagnostics for hierarchical (multi-level/mixed) regression models. R package version 0.4.3. https://CRAN.R-project.org/package=DHARMa

Hinsley S, Bellamy P (2000) The influence of hedge structure, management and landscape context on the value of hedgerows to birds: A review. J Environ Manag 60:33-49. https://doi.org/10.1006/jema.2000. 0360

Hofmann MM, Fleischmann A, Renner SS (2020) Foraging distances in six species of solitary bees with body lengths of 6 to $15 \mathrm{~mm}$, inferred from individual tagging, suggest $150 \mathrm{~m}$-rule-of-thumb for flower strip distances. J Hymenopt Res 77:105-117. https://doi.org/10.3897/jhr.77.51182

Hopfenmüller S, Steffan-Dewenter I, Holzschuh A (2014) Trait-specific responses of wild bee communities to landscape composition, configuration and local factors. PLoS ONE 9:e104439. https://doi.org/10. 1371/journal.pone.0104439

Hutchinson LA, Oliver TH, Breeze TD, Bailes EJ, Brünjes L, Campbell AJ, Erhardt A, de Groot GA, Földesi R, García D, Goulson D, Hainaut H, Hambäck PA, Holzschuh A, Jauker F, Klatt BK, Klein A-M, Kleijn D, Kovács-Hostyánszki A, Krimmer E, McKerchar M, Miñarro M, Phillips BB, Potts SG, Pufal G, Radzevičiūtė R, Roberts SP, Samnegård U, Schulze J, Shaw RF, Tscharntke T, Vereecken NJ, Westbury DB, Westphal C, Wietzke A, Woodcock BA, Garratt MP (2021) Using ecological and field survey data to establish a national list of the wild bee pollinators of crops. Agric Ecosyst Environ 315:107447. https://doi.org/10.1016/j.agee.2021.107447

Inclán DJ, Dainese M, Cerretti P, Paniccia D, Marini L (2016) Spillover of tachinids and hoverflies from different field margins. Basic Appl Ecol 17:33-42. https://doi.org/10.1016/j.baae.2015.08.005

Jauker F, Diekötter T, Schwarzbach F, Wolters V (2009) Pollinator dispersal in an agricultural matrix: opposing responses of wild bees and hoverflies to landscape structure and distance from main habitat. Landsc Ecol 24:547-555. https://doi.org/10.1007/s10980-009-9331-2

Jönsson AM, Ekroos J, Dänhardt J, Andersson GK, Olsson O, Smith HG (2015) Sown flower strips in southern Sweden increase abundances of wild bees and hoverflies in the wider landscape. Biol Conserv 184:51-58. https://doi.org/10.1016/j.biocon.2014.12.027

Kleijn D, van Langevelde F (2006) Interacting effects of landscape context and habitat quality on flower visiting insects in agricultural landscapes. Basic Appl Ecol 7:201-214. https://doi.org/10.1016/j.baae. 2005.07.011

Klein A-M, Brittain C, Hendrix SD, Thorp R, Williams N, Kremen C (2012) Wild pollination services to California almond rely on semi-natural habitat. J Appl Ecol. https://doi.org/10.1111/j.1365-2664.2012. 02144.x

Kremen C, M'Gonigle LK (2015) Small-scale restoration in intensive agricultural landscapes supports more specialized and less mobile pollinator species. J Appl Ecol 52:602-610. https://doi.org/10.1111/13652664.12418

Lefcheck JS (2016) piecewiseSEM: piecewise structural equation modelling in $\mathrm{r}$ for ecology, evolution, and systematics. Methods Ecol Evol 7:573-579. https://doi.org/10.1111/2041-210X.12512

Legendre P, Legendre L (2012) Numerical ecology, 3rd edn. Developments in environmental modelling, vol 24. Elsevier, Amsterdam, Boston

Lenth RV (2016) Least-squares means: the R package ismeans. J Stat Soft. https://doi.org/10.18637/jss. v069.i01

Lowe EB, Groves R, Gratton C (2021) Impacts of field-edge flower plantings on pollinator conservation and ecosystem service delivery - A meta-analysis. Agric Ecosyst Environ 310:107290. https://doi.org/10. 1016/j.agee.2020.107290

Lye G, Park K, Osborne J, Holland J, Goulson D (2009) Assessing the value of rural stewardship schemes for providing foraging resources and nesting habitat for bumblebee queens (Hymenoptera: Apidae). Biol Conserv 142:2023-2032. https://doi.org/10.1016/j.biocon.2009.03.032

Mallinger RE, Gratton C (2015) Species richness of wild bees, but not the use of managed honeybees, increases fruit set of a pollinator-dependent crop. J Appl Ecol 52:323-330. https://doi.org/10.1111/ 1365-2664.12377

Marini L, Quaranta M, Fontana P, Biesmeijer JC, Bommarco R (2012) Landscape context and elevation affect pollinator communities in intensive apple orchards. Basic Appl Ecol 13:681-689. https://doi.org/ 10.1016/j.baae.2012.09.003

Maudsley MJ (2000) A review of the ecology and conservation of hedgerow invertebrates in Britain. J Environ Manage 60:65-76. https://doi.org/10.1006/jema.2000.0362 
Meyer B, Jauker F, Steffan-Dewenter I (2009) Contrasting resource-dependent responses of hoverfly richness and density to landscape structure. Basic Appl Ecol 10:178-186. https://doi.org/10.1016/j.baae. 2008.01.001

Minchin PR (1987) An evaluation of relative robustness of techniques for ecological ordinations. Vegetation 69:89-107

Morandin LA, Kremen C (2013) Hedgerow restoration promotes pollinator populations and exports native bees to adjacent fields. Ecol Appl 23:829-839. https://doi.org/10.1890/12-1051.1

Olsson O, Bolin A, Smith HG, Lonsdorf EV (2015) Modeling pollinating bee visitation rates in heterogeneous landscapes from foraging theory. Ecol Model 316:133-143. https://doi.org/10.1016/j.ecolmodel. 2015.08.009

Osborne JL, Martin AP, Shortall CR, Todd AD, Goulson D, Knight ME, Hale RJ, Sanderson RA (2008) Quantifying and comparing bumblebee nest densities in gardens and countryside habitats. J Appl Ecol 45:784-792. https://doi.org/10.1111/j.1365-2664.2007.01359.x

Ouvrard P, Transon J, Jacquemart A-L (2018) Flower-strip agri-environment schemes provide diverse and valuable summer flower resources for pollinating insects. Biodivers Conserv 27:2193-2216. https:// doi.org/10.1007/s10531-018-1531-0

Pfiffner L, Ostermaier M, Stoeckli S, Müller A (2018) Wild bees respond complementarily to 'high-quality' perennial and annual habitats of organic farms in a complex landscape. J Insect Conserv 22:551-562. https://doi.org/10.1007/s10841-018-0084-6

Pfister SC, Sutter L, Albrecht M, Marini S, Schirmel J, Entling MH (2017) Positive effects of local and landscape features on predatory flies in European agricultural landscapes. Agric Ecosyst Environ 239:283-292. https://doi.org/10.1016/j.agee.2017.01.032

Ponisio LC, M'Gonigle LK, Kremen C (2016) On-farm habitat restoration counters biotic homogenization in intensively managed agriculture. Glob Chang Biol 22:704-715. https://doi.org/10.1111/gcb.13117

Pywell RF, Meek WR, Hulmes L, Hulmes S, James KL, Nowakowski M, Carvell C (2011) Management to enhance pollen and nectar resources for bumblebees and butterflies within intensively farmed landscapes. J Insect Conserv 15:853-864. https://doi.org/10.1007/s10841-011-9383-X

Rader R, Bartomeus I, Garibaldi LA, Garratt MPD, Howlett BG, Winfree R, Cunningham SA, Mayfield MM, Arthur AD, Andersson GKS, Bommarco R, Brittain C, Carvalheiro LG, Chacoff NP, Entling MH, Foully B, Freitas BM, Gemmill-Herren B, Ghazoul J, Griffin SR, Gross CL, Herbertsson L, Herzog F, Hipólito J, Jaggar S, Jauker F, Klein A-M, Kleijn D, Krishnan S, Lemos CQ, Lindström SAM, Mandelik Y, Monteiro VM, Nelson W, Nilsson L, Pattemore DE, Pereira NdO, Pisanty G, Potts SG, Reemer M, Rundlöf M, Sheffield CS, Scheper J, Schüepp C, Smith HG, Stanley DA, Stout JC, Szentgyörgyi H, Taki H, Vergara CH, Viana BF, Woyciechowski M (2016) Non-bee insects are important contributors to global crop pollination. PNAS 113:146-151. https://doi.org/ 10.1073/pnas.1517092112

Ramsden M, Menendez R, Leather S, Wäckers F (2017) Do natural enemies really make a difference? Field scale impacts of parasitoid wasps and hoverfly larvae on cereal aphid populations. Agric Forest Entomol 19:139-145. https://doi.org/10.1111/afe.12191

Reganold JP, Glover JD, Andrews PK, Hinman HR (2001) Sustainability of three apple production systems. Nature 410:926. https://doi.org/10.1038/35073574

Rodríguez-Gasol N, Alins G, Veronesi ER, Wratten S (2020) The ecology of predatory hoverflies as ecosystem-service providers in agricultural systems. Biol Control 151:104405. https://doi.org/10. 1016/j.biocontrol.2020.104405

Rosa García R, Miñarro M (2014) Role of floral resources in the conservation of pollinator communities in cider-apple orchards. Agric Ecosyst Environ 183:118-126. https://doi.org/10.1016/j.agee.2013. 10.017

Samnegård U, Hambäck PA, Smith HG (2019) Pollination treatment affects fruit set and modifies marketable and storable fruit quality of commercial apples. R Soc Open Sci 6:190326. https://doi.org/ 10.1098/rsos. 190326

Sanchez JA, Carrasco A, La Spina M, Pérez-Marcos M, Ortiz-Sánchez FJ (2019) How bees respond differently to field margins of shrubby and herbaceous plants in intensive agricultural crops of the Mediterranean area. Insects. https://doi.org/10.3390/insects11010026

Scheper J, Bommarco R, Holzschuh A, Potts SG, Riedinger V, Roberts SPM, Rundlöf M, Smith HG, Steffan-Dewenter I, Wickens JB, Wickens VJ, Kleijn D (2015) Local and landscape-level floral resources explain effects of wildflower strips on wild bees across four European countries. J Appl Ecol 52:1165-1175. https://doi.org/10.1111/1365-2664.12479

Schirmel J, Albrecht M, Bauer P-M, Sutter L, Pfister SC, Entling MH (2018) Landscape complexity promotes hoverflies across different types of semi-natural habitats in farmland. J Appl Ecol 55:17471758. https://doi.org/10.1111/1365-2664.13095 
Schmidt A, Kirmer A, Kiehl K, Tischew S (2020) Seed mixture strongly affects species-richness and quality of perennial flower strips on fertile soil. Basic Appl Ecol 42:62-72. https://doi.org/10. 1016/j.baae.2019.11.005

Seibold S, Gossner MM, Simons NK, Blüthgen N, Müller J, Ambarlı D, Ammer C, Bauhus J, Fischer M, Habel JC, Linsenmair KE, Nauss T, Penone C, Prati D, Schall P, Schulze E-D, Vogt J, Wöllauer S, Weisser WW (2019) Arthropod decline in grasslands and forests is associated with landscape-level drivers. Nature 574:671-674. https://doi.org/10.1038/s41586-019-1684-3

Staley JT, Bullock JM, Baldock KC, Redhead JW, Hooftman DA, Button N, Pywell RF (2013) Changes in hedgerow floral diversity over 70years in an English rural landscape, and the impacts of management. Biol Conserv 167:97-105. https://doi.org/10.1016/j.biocon.2013.07.033

Sutherland JP, Sullivan MS, Poppy GM (2001) Distribution and abundance of aphidophagous hoverflies (Diptera: Syrphidae) in wildflower patches and field margin habitats. Agric Forest Entomol 3:57-64. https://doi.org/10.1046/j.1461-9563.2001.00090.x

Sutter L, Jeanneret P, Bartual AM, Bocci G, Albrecht M (2017) Enhancing plant diversity in agricultural landscapes promotes both rare bees and dominant crop-pollinating bees through complementary increase in key floral resources. J Appl Ecol 54:1856-1864. https://doi.org/10.1111/1365-2664. 12907

Sutter L, Albrecht M, Jeanneret P (2018) Landscape greening and local creation of wildflower strips and hedgerows promote multiple ecosystem services. J Appl Ecol 55:612-620. https://doi.org/10.1111/ 1365-2664.12977

Tschumi M, Albrecht M, Collatz J, Dubsky V, Entling MH, Najar-Rodriguez AJ, Jacot K (2016) Tailored flower strips promote natural enemy biodiversity and pest control in potato crops. J Appl Ecol 53:1169-1176. https://doi.org/10.1111/1365-2664.12653

van Rijn PC, Kooijman J, Wackers FL (2006) The impact of floral resources on syrphid performance and cabbage aphid biological control. IOBC WPRS Bull 29:149-152

Westrich P (2018) Die Wildbienen Deutschlands. Eugen Ulmer KG, Stuttgart, Germany.

Westrich P, Frommer U, Mandery K, Riemann H, Ruhnke H, Saure C, Voith J (2012) Rote Liste und Gesamtartenliste der Bienen (Hymenoptera, Apidae) Deutschlands: 5. Fassung, Stand Februar 2011. Naturschutz Und Biologische Vielfalt 70:373-416

Wood TJ, Holland JM, Goulson D (2017) Providing foraging resources for solitary bees on farmland: current schemes for pollinators benefit a limited suite of species. J Appl Ecol 54:323-333. https:// doi.org/10.1111/1365-2664.12718

Publisher's Note Springer Nature remains neutral with regard to jurisdictional claims in published maps and institutional affiliations. 